\title{
Thioviridamide, a Novel Apoptosis Inducer in Transformed Cells from Streptomyces olivoviridis
}

\author{
Yoichi Hayakawa, Kahori Sasaki, Hisashi Adachi, Keiko Furihata, Koji Nagai, \\ Kazuo Shin-ya
}

Received: September 28, 2005 / Accepted: December 13, 2005

(C) Japan Antibiotics Research Association

\begin{abstract}
In the course of screening for antitumor antibiotics using $3 \mathrm{Y} 1$ rat fibroblasts transformed with adenovirus oncogenes, a new active substance designated thioviridamide was isolated from the culture broth of an actinomycete. The producing organism was identified as Streptomyces olivoviridis on the basis of its culture characteristics and physiological properties. Thioviridamide showed cytotoxicity selectively against Ad12-3Y1 cells $\left(\mathrm{IC}_{50}=3.9 \mathrm{ng} / \mathrm{ml}\right)$ and $\mathrm{E} 1 \mathrm{~A}-3 \mathrm{Y} 1$ cells $\left(\mathrm{IC}_{50}=32 \mathrm{ng} / \mathrm{ml}\right)$, both of which contain the adenovirus E1A oncogene. Significant numbers of Ad12-3Y1 cells treated with thioviridamide contained condensed chromatin and fragmented nuclei, indicating that thioviridamide induced apoptosis.
\end{abstract}

Keywords thioviridamide, antitumor antibiotics, apoptosis, Streptomyces, adenovirus oncogene

\section{Introduction}

The retinoblastoma tumor suppressor protein ( $\mathrm{pRB}$ ) plays an important role in cell-cycle and apoptosis control in mammalian cells, and is inactivated during the development of a wide variety of human cancers $[1,2]$. The adenovirus E1A gene product inactivates $\mathrm{pRB}$ thereby stimulating host cell DNA synthesis. However, this function of E1A induces the host cells to undergo apoptosis. For this reason, adenoviruses encode a second function in the E1B gene that prolongs host cell viability by inhibiting apoptosis [3, 4]. At low frequency, rodent cells are transformed by E1A alone, and the stable transformants expressing E1A seem to exhibit an attenuated apoptotic response to E1A [3]. It is clear that pRB-inactivated cells require additional genetic alterations that render them resistant to apoptotic stimuli. E1A/E1B-transformed cells and E1A-transformed cells might be appropriate models for pRB-inactivated tumor cells that suppress apoptosis by known and unknown mechanism, respectively.

In the course of screening for antitumor antibiotics using $3 \mathrm{Y} 1$ rat fibroblasts transformed with adenovirus oncogenes, an actinomycete identified as Streptomyces olivoviridis was found to produce an active substance designated thioviridamide (Fig. 1), which was determined to be a novel cyclic peptide containing five thioamide groups by NMR spectral analysis. Thioviridamide induced apoptotic cell death selectively in 3 Y1 rat fibroblasts transformed with adenovirus type 12 or its E1A gene. This paper describes the fermentation, isolation, physico-chemical properties and biological activities of thioviridamide as well as the taxonomy of the producing organism. The structure elucidation of thioviridamide is described in the accompanying paper [5].
Y. Hayakawa (Corresponding author): Faculty of Pharmaceutical Sciences, Tokyo University of Science, 2641 Yamazaki, Noda, Chiba 278-8510, Japan.

E-mail: hykw@rs.noda.tus.ac.jp
K. Sasaki, H. Adachi, K. Furihata, K. Shin-ya: Institute of Molecular and Cellular Biosciences, The University of Tokyo, Bunkyo-ku, Tokyo 113-0032, Japan.

K. Nagai: Fermentation Research Labs., Astellas Pharma Inc., 5-2-3, Toukoudai, Tsukuba, Ibaraki 305-2698, Japan. 


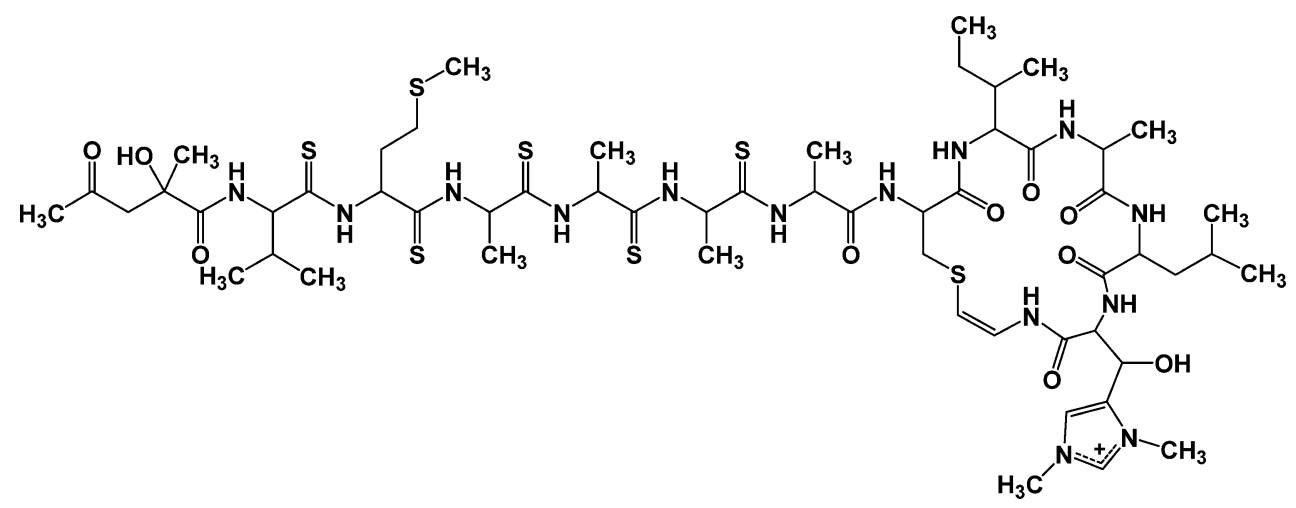

Fig. 1 Structure of thioviridamide.

\section{Materials and Methods}

\section{General}

UV and IR spectra were measured on Hitachi U-3210 and JASCO FT/IR-470plus spectrometers, respectively. Mass spectra were obtained on a JEOL HX-110 spectrometer in the FAB mode using $m$-nitrobenzyl alcohol as matrix and polyethylene glycol as internal standard. Optical rotations were recorded on a JASCO DIP-1000 spectropolarimeter.

\section{Microorganism}

The producing organism designated NA05001 was isolated from a soil sample collected at Ogasawara-mura, Tokyo, Japan. Strain NA05001 was deposited in the National Institute of Bioscience and Human-Technology, Agency of Industrial Science and Technology, Japan, with the name of Streptomyces olivoviridis NA05001 under accession No. FERM BP-10289.

\section{Taxonomy}

The characterization and identification of the culture were carried out by the method of the International Streptomyces Project (ISP) [6, 7]. For the evaluation of culture characteristics, the strain was incubated at $27^{\circ} \mathrm{C}$ for 21 days. Cell wall composition was analyzed by the methods of Becker [8].

\section{Cells and Cell Culture}

Rat 3Y1 fibroblasts and 3Y1-derived cell lines [9 11] were obtained from the Japanese Cancer Research Resources Bank (JCRB). The cells were cultured in Dulbecco's modified Eagle's medium supplemented with $10 \%$ heatinactivated fetal calf serum and $0.1 \%$ glucose.

\section{MTT Assay}

Cells at 50\% confluence were plated at one tenth lower cell density and incubated for 3 days with various concentrations of a sample. The growth was measured by formazan formation (detected at $570 \mathrm{~nm}$ ) after treatment of the cells with $0.5 \mathrm{mg} / \mathrm{ml}$ of 3-(4,5-dimethylthiazol-2-yl)2,5-diphenyltetrazolium bromide (MTT) for 4 hours at $37^{\circ} \mathrm{C}$. $\mathrm{IC}_{50}$ values were calculated from the concentrationinhibition response curves. The $\mathrm{IC}_{50}$ values were calculated by linear interpolation between the two drug concentrations above and below the 50\% inhibition line.

\section{Apoptosis Assay}

Cells were treated with $0.4 \mu \mathrm{g} / \mathrm{ml}$ of thioviridamide for 18 hours, and adherent and nonadherent cells were pooled. Chromatin structure was visualized by fluorescence microscopy after staining fixed cells $\left(1 \times 10^{6}\right.$ cells $)$ with Hoechst Dye 33258.

\section{Results and Discussion}

\section{Identification of the Producing Organism}

The aerial mycelium of culture NA05001 irregularly branched on the long main stem and terminated in straight spore chains, hooked spore chains or rarely in compact loops, forming spore chains with 10 50 spores per chain. The spores were oval in shape $(0.4 \sim 0.6 \times 1.0 \sim 1.4 \mu \mathrm{m})$ with a spiny surface. Whole-cell analysis showed that the strain contained L,L-diaminopimelic acid, indicating cellwall type I. The culture characteristics and physiological properties of NA05001 are summarized in Tables 1 and 2, respectively. On the basis of these characteristics, strain NA05001 seems to belong to the genus Streptomyces. Among the species of Streptomyces described in Shirling's reports [12 15], these properties resemble those of 
Table 1 Culture characteristics of strain NA05001

\begin{tabular}{llll}
\hline \multicolumn{1}{c}{ Agar medium } & Aerial mycelium & Substrate mycelium & Soluble pigment \\
\hline $\begin{array}{l}\text { Sucrose- nitrate } \\
\text { Glucose- asparagine }\end{array}$ & Gray-color series & Pale yellow & None \\
Glycerol - asparagine & Gray-color series & Pale yellowish brown & None \\
Inorganic salts-starch & Gray-color series & Pale yellowish brown & None \\
Tyrosine & Gray-color series & Dark brownish gray & Pale yellowish brown \\
Nutrient & No aerial mycelium & Pale yellow & None \\
Yeast extract-malt extract & Gray-color series & Yellowish brown to & Pale yellowish brown \\
& & pale yellowish brown & None \\
Oatmeal & Gray-color series & Light yellow to & pale yellowish brown
\end{tabular}

Table 2 Comparison of strain NA05001 with Streptomyces olivoviridis

\begin{tabular}{|c|c|c|}
\hline & NA05001 & $\begin{array}{c}\text { Streptomyces } \\
\text { olivoviridis }^{a}\end{array}$ \\
\hline \multicolumn{3}{|c|}{ Spore chain morphology } \\
\hline Straight & + & + \\
\hline Hooks & + & + \\
\hline Loops & + & + \\
\hline \multicolumn{3}{|l|}{ Spore surface } \\
\hline Spiny & + & + \\
\hline \multicolumn{3}{|l|}{ Color of colony } \\
\hline Gray & + & + \\
\hline \multicolumn{3}{|l|}{ Reverse color } \\
\hline Distinctive & + & + \\
\hline Olive & + & + \\
\hline $\mathrm{pH}$ sensitivity & - & - \\
\hline \multicolumn{3}{|l|}{ Soluble pigment } \\
\hline Production & + & + \\
\hline pH sensitivity & - & - \\
\hline Melanoid pigment & + & + \\
\hline Hydrolysis of starch & + & + \\
\hline Nitrate reduction & - & - \\
\hline Growth at $45^{\circ} \mathrm{C}$ & - & - \\
\hline \multicolumn{3}{|c|}{ Utilization of carbon source } \\
\hline L-Arabinose & + & + \\
\hline D-Xylose & + & + \\
\hline i-Inositol & + & - \\
\hline D-Mannit & + & + \\
\hline L-Rhamnose & + & + \\
\hline Raffinose & + & - \\
\hline Sucrose & + & - \\
\hline D-Fructose & + & + \\
\hline
\end{tabular}

a Properties have been reported [13].
Streptomyces olivoviridis. A comparison of strain NA05001 with S. olivoviridis [13] as shown in Table 2 gave a good agreement except for carbon utilization, and therefore, culture NA05001 was identified as a strain of Streptomyces olivoviridis.

\section{Fermentation}

The seed medium consisted of soluble starch $1.0 \%$, molasses $1.0 \%$, meat extract $1.0 \%$ and Polypepton $1.0 \%$ (pH 7.2). Seed tubes containing $15 \mathrm{ml}$ of the medium were inoculated with a stock culture of the producing strain maintained on a Bennett's agar slant and were incubated on a reciprocal shaker at $27^{\circ} \mathrm{C}$ for 2 days. The seed culture at $2 \%$ was transferred to $500-\mathrm{ml}$ Erlenmeyer flasks containing $100 \mathrm{ml}$ of a production medium consisting of glucose $2.5 \%$, fish meal $1.5 \%$, dry yeast $0.2 \%$ and calcium carbonate $0.4 \%$ (pH 7.2). The fermentation was carried out on a rotary shaker at $27^{\circ} \mathrm{C}$ for 4 days.

\section{Isolation}

The fermentation broth (2 liters) was centrifuged and the mycelium was extracted with acetone. After evaporation, the aqueous concentrate was extracted with ethyl acetate at $\mathrm{pH}$ 5.0. The extract was applied to a silica gel column, which was washed with chloroform-methanol $(10: 1)$ and eluted with chloroform - methanol $(2: 1)$. The active eluate was subjected to HPLC (YMC Pack D-ODS-7, $20 \times 250 \mathrm{~mm}$ ) with $85 \%$ methanol containing $5 \mathrm{mM}$ disodium hydrogen citrate. The active fraction was concentrated and then partitioned between ethyl acetate and water. The organic layer was successively washed with water, $0.01 \mathrm{M}$ hydrochloric acid and water. The ethyl acetate solution was dried over anhydrous sodium sulfate and evaporated to dryness to give a chloride salt of thioviridamide $(2.7 \mathrm{mg})$. 
Table 3 Physico-chemical properties of thioviridamide chloride

\begin{tabular}{ll}
\hline Appearance & Colorless powder \\
MP & $146 \sim 150^{\circ} \mathrm{C}$ \\
{$[\alpha]_{D}^{23}$} & $-146^{\circ}(c 0.285, \mathrm{MeOH})$ \\
Molecular formula & $\mathrm{C}_{56} \mathrm{H}_{93} \mathrm{~N}_{14} \mathrm{O}_{10} \mathrm{~S}_{7} \mathrm{Cl}$ \\
HR-FAB-MS $(\mathrm{m} / \mathrm{z})$ & \\
$\quad$ Found & $1345.5215(\mathrm{M}-\mathrm{Cl})^{+}$ \\
$\quad$ Calcd. & 1345.5244 \\
UV $\lambda_{\max }^{\operatorname{maOH}} \mathrm{nm}(\varepsilon)$ & $247(\mathrm{sh} .29,000), 274(31,500)$ \\
IR $v_{\max }(\mathrm{KBr}) \mathrm{cm}^{-1}$ & $3350,1710(\mathrm{sh}), 1670,1530$. \\
\hline
\end{tabular}

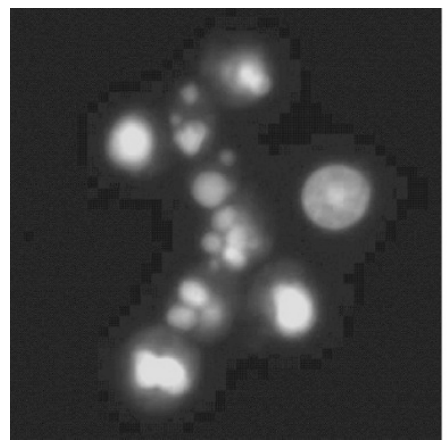

Table 4 Antitumor activity of thioviridamide against transformed rat fibroblasts

\begin{tabular}{llc}
\hline Cell line & \multicolumn{1}{c}{ Oncogene } & $\mathrm{IC}_{50}(\mathrm{ng} / \mathrm{ml})$ \\
\hline 3Y1 & & 890 \\
Ad12-3Y1 & E1A, E1B & 3.9 \\
E1A-3Y1 & E1A & 32 \\
SR-3Y1 & V-SrC & 630 \\
SV-3Y1 & SV40 large T antigen & 460 \\
HR-3Y1 & V-H-ras & 200 \\
\hline
\end{tabular}

Fig. 2 Fluorescence micrographs of Ad12-3Y1 cells stained with Hoechst Dye 33258. Cells were cultured for 18 hours with (left) or without (right) $0.4 \mu \mathrm{g} / \mathrm{ml}$ of thioviridamide.

\section{Physico-chemical Properties}

The physico-chemical properties of thioviridamide chloride are summarized in Table 3. The molecular formula of thioviridamide was established to be $\mathrm{C}_{56} \mathrm{H}_{93} \mathrm{~N}_{14} \mathrm{O}_{10} \mathrm{~S}_{7}{ }^{+}$(ion) by high-resolution FAB-MS. The IR spectrum of thioviridamide chloride indicates the presence of ketone $\left(1710 \mathrm{~cm}^{-1}\right)$ and amide $\left(1670 \mathrm{~cm}^{-1}\right)$ groups.

\section{Biological Activity}

The antitumor activity of thioviridamide was examined by using $3 \mathrm{Y} 1$ rat normal fibroblasts and $3 \mathrm{Y} 1$ cells transformed with adenovirus type 12 (Ad12-3Y1), adenovirus E1A gene (E1A-3Y1), SV40 (SV-3Y1), v-src (SR-3Y1) or v-H-ras (HR-3Y1) [9 11]. Thioviridamide showed selective cytotoxicity against Ad12-3Y1 cells $\left(\mathrm{IC}_{50}=3.9 \mathrm{ng} / \mathrm{ml}\right)$ and E1A-3Y1 cells $\left(\mathrm{IC}_{50}=32 \mathrm{ng} / \mathrm{ml}\right)$, both of which contain the adenovirus E1A oncogene (Table 4). At higher concentrations, thioviridamide inhibited the growth of the other cell-lines including normal fibroblasts without distinct cell death. The cytotoxicity of thioviridamide seems to not be affected by a typical growth stimulator such as Ras or Src. During apoptosis, loss of membrane integrity is typically preceded by chromatin condensation and nuclear fragmentation [16]. Significant numbers of Ad12-3Y1 cells treated with $0.4 \mu \mathrm{g} / \mathrm{ml}$ of thioviridamide for 18 hours contained condensed chromatin and fragmented nuclei as visualized by staining with Hoechst Dye 33258 (Fig. 2), suggesting that cell death induced by thioviridamide resulted from a programmed cellular response, apoptosis. Since E1B-containing Ad12-3Y1 cells were highly sensitive to thioviridamide, the E1B antiapoptotic gene appears to not prevent cell death induced by thioviridamide. Interestingly, thioviridamide did not induce apoptosis in SV-3Y1 cells, although SV40 large T antigen can inactivate $p R B$ in a manner like E1A. It has been reported that E1A can induce apoptosis in pRB-deficient cells [17]. Thioviridamide might stimulate the apoptotic signal from E1A independent of $\mathrm{pRB}$. These results suggested that thioviridamide is a possible candidate for an anticancer agent against tumor cells expressing an E1A-like oncogene. Further studies on the biological activities of thioviridamide are in progress.

Acknowledgements This work was supported in part by a Grant-in-Aid for Scientific Research, The Ministry of Education, Science, Sports and Culture, Japan. 


\section{References}

1. Cobrinik D, Dowdy S, Hinds P, Mittnacht S, Weinberg R. The retinoblastoma protein and the regulation of cell cycling. Trends Biochem Sci 17: 312-315 (1992)

2. Morgenbesser SD, Williams BO, Jacks T, DePinho RA. p53 dependent apoptosis produced by Rb-deficiency in the developing mouse lens. Nature 371: 72-74 (1994)

3. Debbas M, White E. Wild-type p53 mediates apoptosis by E1A, which is inhibited by E1B. Genes Dev 7: 546-554 (1993)

4. Yew PR, Berk AJ. Inhibition of p53 transactivation required for transformation by adenovirus early $1 \mathrm{~B}$ protein. Nature 357: 82-85 (1992)

5. Hayakawa Y, Sasaki K, Nagai K, Shin-ya K, Furihata K. Structure of thioviridamide, a novel apoptosis inducer from Streptomyces olivoviridis. J Antibiot 59: 6-10 (2006)

6. Shirling EB, Gottlieb D. Methods for characterization of Streptomyces species. Int J Syst Bacteriol 16: 313-340 (1966)

7. Nonomura H. Key for classification and identification of 458 species of the streptomyces included in ISP. J Ferment Technol 52: 78-92 (1974)

8. Becker BM, Lechevalier P, Lechevalier HA. Chemical composition of cell wall preparations from strains of various genera of aerobic actinomycetes. Appl Microbiol 13: 236-243 (1965)

9. Kimura G, Itagaki A, Summers J. Rat cell line 3Y1 and its virogenic polyoma- and SV40-transformed derivatives. Int J Cancer 15: 694-706 (1975)
10. Zaitsu H, Tanaka H, Mitsudomi T, Matsuzaki A, Ohtsu M, Kimura G. Differences in proliferation properties among sublines of rat $3 \mathrm{Y} 1$ fibroblasts transformed by various agents in vitro. Biomed Res 9: 181-197 (1988)

11. Shimura H, Mitsudomi T, Matsuzaki A, Kabemura M, Okuda A, Kimura G. Transformation by v-H-ras does not restore proliferation of a set of temperature-sensitive cellcycle mutants of rat 3Y1 fibroblasts. Cell Structure and Function 15: 211-219 (1990)

12. Shirling EB, Gottlieb D. Cooperative description of type cultures of Streptomyces. II. Species descriptions from first study. Int J Syst Bacteriol 18: 69-189 (1968)

13. Shirling EB, Gottlieb D. Cooperative description of type cultures of Streptomyces. III. Additional species descriptions from first and second studies. Int $\mathrm{J}$ Syst Bacteriol 18: 279-392 (1968)

14. Shirling EB, Gottlieb D. Cooperative description of type cultures of Streptomyces. IV. Species descriptions from second, third and fourth studies. Int J Syst Bacteriol 19: 391-512 (1969)

15. Shirling EB, Gottlieb D. Cooperative description of type cultures of Streptomyces. V. Additional species descriptions. Int J Syst Bacteriol 22: 265-394 (1972)

16. Wyllie AH. Glucocorticoid-induced thymocyte apoptosis is associated with endogenous endonuclease activation. Nature 284: 555-556 (1980)

17. Samuelson AV, Lowe SW. Selective induction of p53 and chemosensitivity in RB-deficient cells by E1A mutants unable to bind the RB-related proteins. Proc Natl Acad Sci USA 94: 12094-12099 (1997) 
